\title{
Novel Enantiopure Bis(pyrrolo)tetrathiafulvalene Donors Exhibiting Chiral Crystal Packing Arrangements.
}

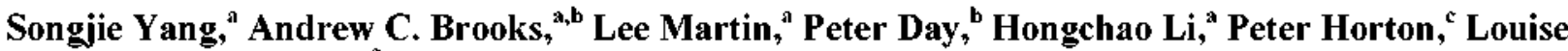 \\ , Male, John D. Wallis ${ }^{\text {* }^{*}}$
}

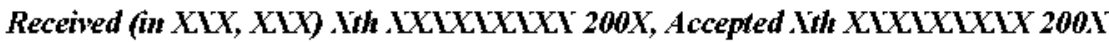

First published on the web . Vth XXVXXVXVX 200X

DOI: $10.1039 / 600000 x$

Two novel enantiopure bis(pyrrolo[3,4-d])tetrathiafulvalene 10 derivatives, substrates for preparing chiral conducting materials, show chiral crystal packing arrangements in which successive layers are rotated in accordance with an exact or approximate $4_{3}$ axis. The corresponding donors containing fused dihydropyrrole groups, and thus four more hydrogen is atoms, form stacks along a crystal axis.

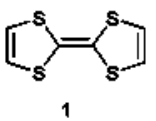<smiles>C[C@H]1SC2=C(SC(=C3SC4=C(S3)S[C@H](C)[C@@H](C)S4)S2)S[C@@H]1C</smiles>

3

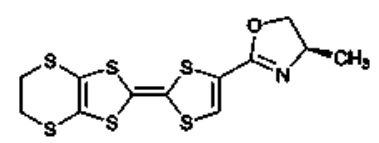<smiles>C1CSC2=C(S1)SC(=C1SC3=C(SCCS3)S1)S2</smiles><smiles>OC[C@H](O)[C@H]1SC2=C(SC(=C3SC4=C(SCCS4)S3)S2)S[C@@H]1[C@H](O)CO</smiles><smiles></smiles>

The influence of chirality on the electrical properties of materials has been a topic of discussion for many years, ${ }^{1}$ and 20 Rikken has recently proposed and demonstrated the phenomenon of electrical magnetochiral anisotropy in carbon nanotubes. ${ }^{2}$ Radical cation salts of donors such as TTF 1 and BEDT-TTF 2 provide a family of materials for investigating this phenomenon if chirality can be incorporated in the system. A range of s enantiopure or enantioenriched donors related to 2 with stereogenic centres at carbon ${ }^{3}$ or sulfur ${ }^{4}$ e.g. 3-6 have been prepared, but to date no radical cation salts with significant differences in packing arrangements between enantiomers have been prepared, due to the strong tendency of these donor 30 molecules to pack face-to-face and often related by pseudocentrosymmetry. Two comparisons of racemic and enantiopure salts, though, have been described. ${ }^{5}$ Salts with an enantiopure chiral anion ${ }^{6}$ or solvent molecule ${ }^{7}$ have also been studied. Day has demonstrated how the organization of the $\Delta$ and $\Lambda$ is enantiomers of chromium(III) tris(oxalate) influences the electrical properties of polymorphs of racemic $\mathrm{ET}_{4}\left[\left(\mathrm{H}_{3} \mathrm{O}\right) \mathrm{Cr}\left(\mathrm{C}_{2} \mathrm{O}_{4}\right)_{3}\right] \cdot \mathrm{C}_{6} \mathrm{H}_{5} \mathrm{CN}^{8}$ and Martin has prepared the first conducting salt containing a single enantiomer in the series $\mathrm{ET}_{3}\left(\mathrm{X}^{+}\right)$-M(III $)\left(\mathrm{C}_{2} \mathrm{O}_{4}\right)_{3}$. guest. ${ }^{\circ}$ Nevertheless, the preparation of to chiral packing arrangements for the organosulfur donors has remained elusive ${ }^{10}$ though helical systems containing TTF or $\beta$ fused thiophenes are emerging as potential systems for study. " Now we report four new enantiopure donors 7-10 based on the bis(pyrrolo[3,4-d]tetrathiafulvalene system and the helical-type 45 chiral packing arrangements of donors 8 and $\mathbf{1 0}$, an important stepping stone to the production of electroactive materials with chiral packing arrangements.

The preparative route (Scheme) builds on Becher's approach to bis(pyrrolo)TTF. ${ }^{12,13}$ The structures of the four donors 7-10 so were measured by X-ray crystallography at $120 \mathrm{~K}^{14}$ Donors 7

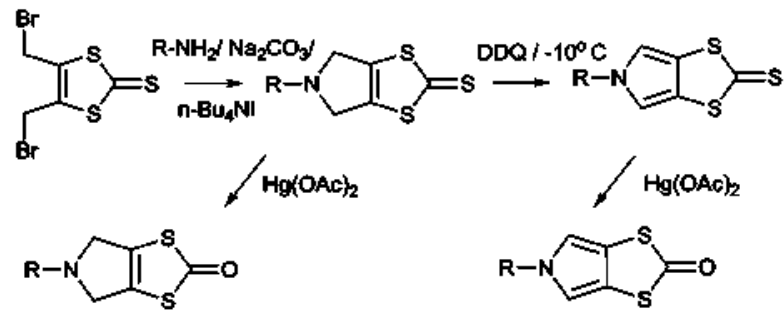

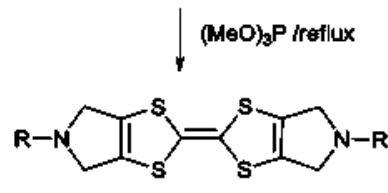

$7 \mathrm{R}=$ S-1-phenylethy| $9 \mathrm{R}=R-1-(1$-naphthyl)ettry

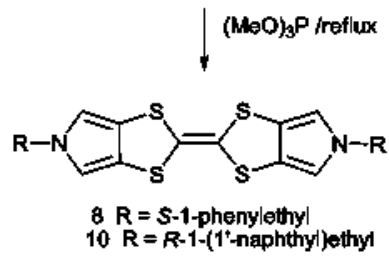

10 $R=R-1-\left(1^{*}-\right.$ naphthyl)ethyl
Scheme: Synthetic route to donors 7-10

55

and 9 containing dihydropyrole rings form stacks in the crystal, while, remarkably, donors $\mathbf{8}$ and $\mathbf{1 0}$, containing just four less hydrogen atoms but with planar bonding geometry at nitrogen rather than pyramidal bonding geometry, form helical type crystal ${ }_{60}$ packing arrangements. Molecular structures are shown in Figure 1 , with packing arrangements in Figures 2-5. Compared to the donors 7 and 9 , the bond lengths in most parts of the pyrrole rings of 10 and 12 are notably shorter, e.g. C-N bonds, 1.358(6)$1.381(6) \AA$ compared to $1.474(4)-1.495(8) \AA$ and unfused $C-C$ 6s bonds $1.360(8)-1.373(6) \AA$ compared to $1.481(9)-1.499(9) \AA$, while the bond at the ring fusion is longer $1.408(6)-1.417(6) \AA$ compared to $1.336(7)-1.343(4) \AA$. Donor 8 which carries two 1 phenylethyl groups crystallises in the tetragonal space group $\mathrm{P}_{3} 2_{1} 2$ with four donor molecules in the unit cell which are 7o related by the four fold screw axis along the $c$ axis which is 42.205 $\AA$ long. Each donor is bisected by a two fold crystallographic axis in the plane of the donor system, so only half the donor is crystallographically unique. Donor 10 which differs from 8 by replacement of the phenyl rings with naphthyl 75 rings, adopts a similar packing arrangement but in orthorhombic space group $\mathrm{C} 222_{1}$, with the $a$ and $b$ axes almost equal (10.8652(2) and $10.8969(2) \AA)$ and with two independent donor 
molecules, each of which is bisected by its own two fold crystallographic rotation axis along the $a$ or $b$ axis. There are four layers of donors lying perpendicular to the $c$ axis, which are nearly related by a four fold screw axis. Thus, these two donors $s$ have axially chiral packing arrangements.
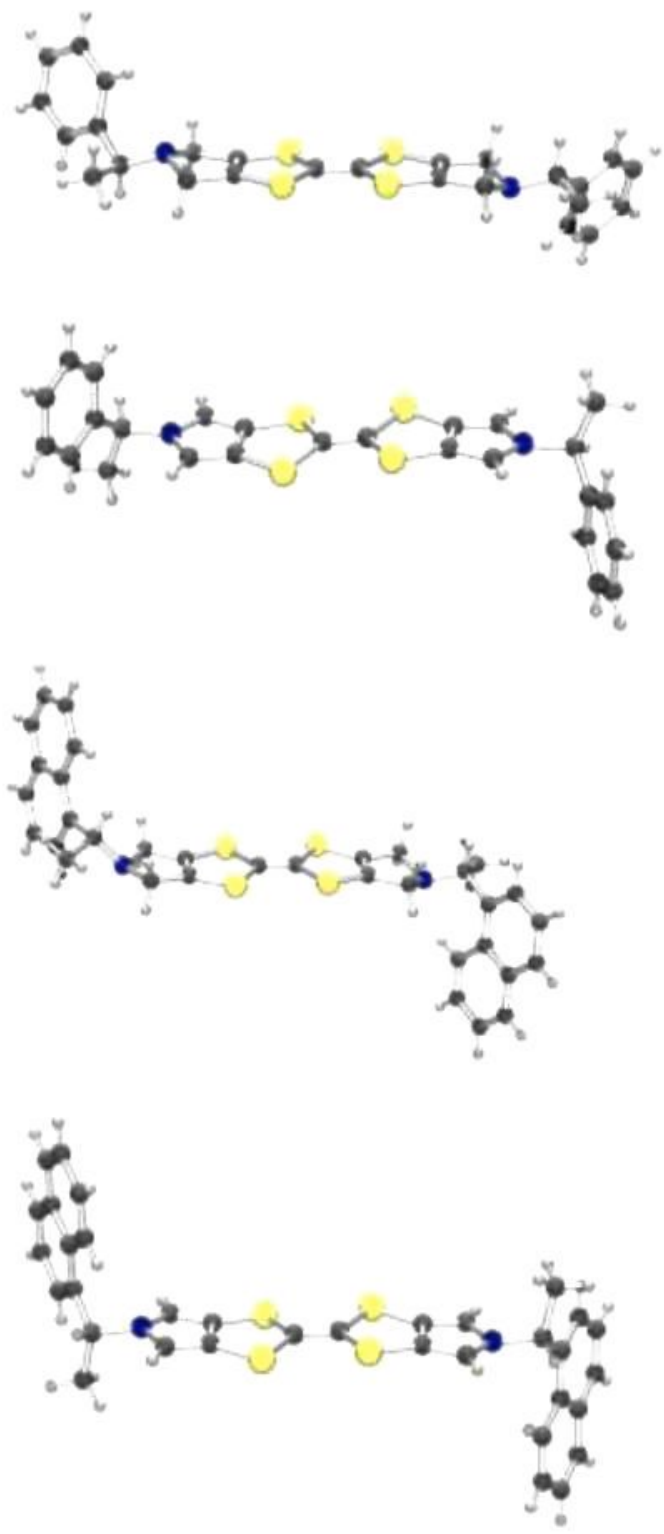

Figure 1: Molecular structures of donors 7-10 ${ }^{14}$

The molecules of the phenyl substituted donor 8 are arranged in layers perpendicular to the $c$ axis such that their 15 bis(pyrrolo)TTF planes lie at $26.5^{\circ}$ to the $a b$ plane. Each $\mathrm{S}$ atom is involved in a close contact with a $\mathrm{S}$ atom of a neighbouring molecule in the layer (S...S 3.402(2) $\AA$ ). The relative rotation of adjacent planes of molecules originates in the orientations of the phenyl groups. The conformation about the exocyclic N-C bond

20 places the bond from the stereogenic centre to the methyl group almost perpendicular to the pyrrole plane so that the axis of the phenyl group makes torsion angles of $40.5^{\circ}$ and $-142.0^{\circ}$ to the ring $\mathrm{N}-\mathrm{C}$ bonds. The two phenyl groups are twisted so that their planes lie at $80^{\circ}$ to exocyclic N-C bonds and are directed out ${ }_{25}$ from opposite faces of the donor molecule. It is the interlocking of phenylethyl groups between layers which controls the packing arrangement (Fig 2). The donor molecules form layers in the $a b$ plane, which leave grooves between lines of parallel phenyl groups, into which the phenyl groups from the layer above insert. ${ }_{30}$ The angle between the phenyl planes of interlocking layers is $36.6^{\circ}$. Inside the groove the para $\mathrm{H}$ atom of the benzene ring butts up against the pyrrole ring of a molecule in the next layer, with a $\mathrm{H}-\mathrm{-C}$ contact to an $\alpha-\mathrm{C}$ atom of the pyrrole ring of $2.71 \AA$. The para $\mathrm{C}$ atom and one of the meta $\mathrm{C}$ atoms make contacts of 35 2.68 and $2.80 \AA$ with the $\mathrm{H}$ atom from the stereogenic centre of a molecule in the next layer.

The molecular conformations and packing arrangement of donor $\mathbf{1 0}$ are very similar to those of donor $\mathbf{8}$, except that there are two molecules which form independent layers perpendicular 40 to the $c$ axis, and that the stereogenic centres are displaced slightly $(0.24-0.27 \AA)$ from their pyrrole planes. The orientation of the aromatic ring is similar in both molecules, and close to that in donor $\mathbf{8}$; the bond from the stereogenic centre to the naphthyl group makes torsion angles of -48.6 and 147.0 or -46.6 and 45 $148.1^{\circ}$ with the endocyclic N-C bonds, and the naphthyl rings are twisted to lie at 72 and $74^{\circ}$ to the exocyclic N-C bonds. The planes of the bis(pyrrolo)TTF molecules lie $c a 28^{\circ}$ to the $a b$ plane for both molecules. Within the two crystallographically unique layers molecules are related by the $\mathrm{C}$ centring, while the two

so

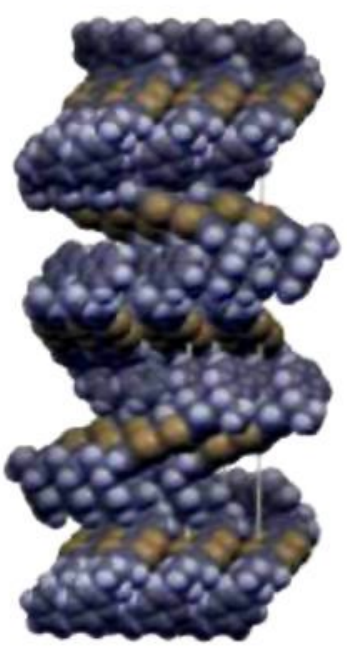

Figure 2. Packing of layers of 8 related by a $4_{3}$ axis, viewed with $c$ axis vertical. ${ }^{14}$

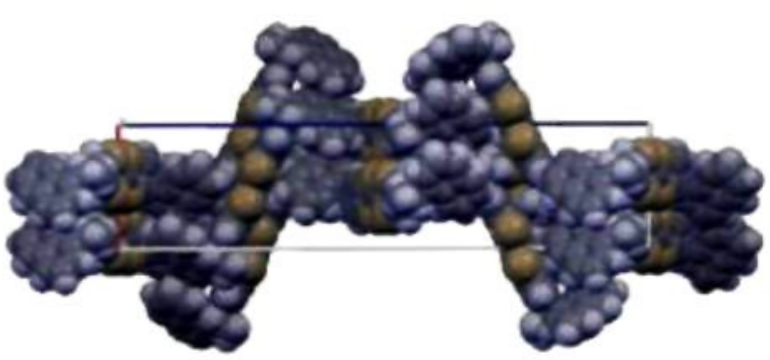

Figure 3 . Crystal packing of $\mathbf{1 0}$ viewed along the $a$ axis, with the $c$ axis horizontal. ${ }^{14}$ 
further layers perpendicular to $c$ within the unit cell are generated by the $2_{1}$ axis (Fig. 3). Within the two unique layers, the donor molecules makes short $\mathrm{S}$...S contacts with other molecules from all four S atoms (S...S 3.5730(16) and 3.6456(16) $\AA$ ) which 5 indicate a slightly greater spacing than in the crystals of $\mathbf{8}$. Following the pattern from $\mathbf{8}$, the naphthyl groups of one layer slip into the grooves created by the naphthyl rings in the adjacent layer and lie at $26.1^{\circ}$ to each other. The closest contacts at these interfaces are between the $5-\mathrm{H}$ of the naphthyl system and a 10 carbon at the fusion of pyrrole and dithiole rings $(2.68 \& 2.72 \AA)$. Trans, trans-tetra(ethyl)BEDT-TTF has been reported to resolve on crystallization to give tetragonal crystals in $\mathrm{P}_{3} 2_{1} 2$, but the structure is not analogous to those described here. ${ }^{15}$

Donors 7 and 9, contain pyramidal $\mathrm{N}$ atoms with each $\mathrm{N}$ 15 atom lying $0.399-0.426 \AA$ out of the plane of its three substituents. The conformation about the exocyclic N-C bonds places the $\mathrm{H}$ atom of the stereogenic centre roughly anti to the nitrogen lone pair in both molecules. In the phenyl substituted donor 7 both dihydropyrrole rings adopt envelope configurations 20 with the $\mathrm{N}$ atoms lying anti to each other, 0.422 and $-0.392 \AA$ out of the best plane of their respective pyrrole ring carbon atoms. The chiral substituents adopt pseudo-equatorial

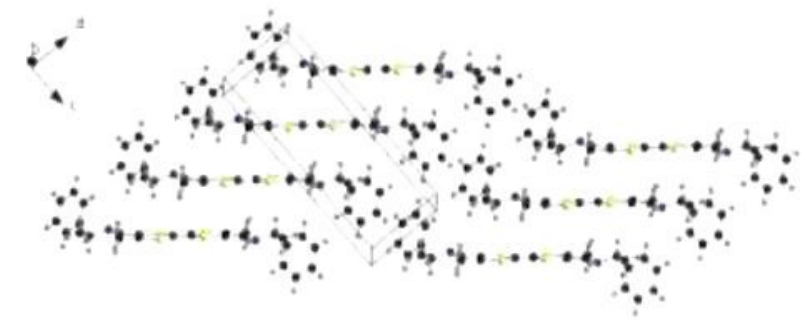

${ }_{25}$ Figure 4: Crystal packing of donor 7 viewed down the $b$ axis. ${ }^{14}$

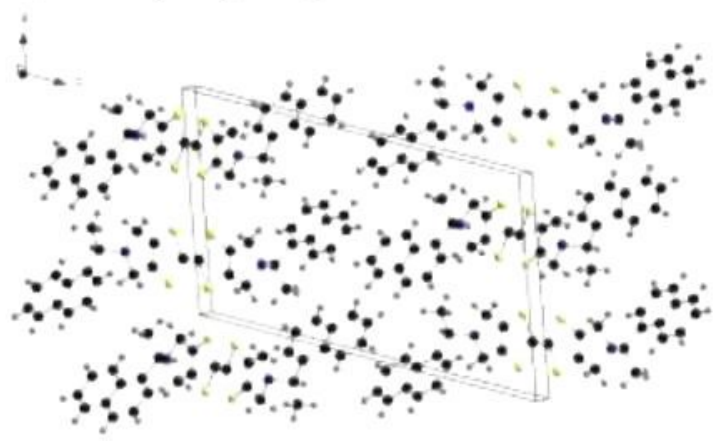

Figure 5: Crystal packing of donor 10 viewed down the $b$ axis. ${ }^{14}$

positions so that neither stereogenic centre lies more than $0.11 \AA$ 30 out of the best plane of the TTF ring system. In contrast, in the naphthyl substituted donor 9 although both $\mathrm{N}$ atoms have pyramidal geometry, the dihydropyrrole ring conformations are different. One adopts a strong envelope conformation with the $\mathrm{N}$ atom lying $0.401 \AA$ out of the plane of the pyrrole ring carbon 35 atoms, with the chiral substituent taking up a pseudo-equatorial position and the naphthalene substituent oriented so its peri $\mathrm{H}$ atom makes a short contact with the ring $\mathrm{N}$ atom of just $2.46 \AA$. In contrast, the second dihydropyrrole ring is close to planar with the $\mathrm{N}$ atom lying just $0.080 \AA$ out of the plane of the other four 40 ring atoms, and the naphthalene is oriented with the ortho $\mathrm{H}$ atom, and not the peri $\mathrm{H}$ atom, near to the $\mathrm{N}$ atom $(\mathrm{N}$... H 2.61
$\AA$ ). The two stereogenic centres lie 0.175 and $1.108 \AA$ to opposite sides of the best plane of the TTF system.

The chirality of the side chains has not forced these two 45 donors to adopt helical-type packing arrangements. Donor 7 forms slipped stacks in the triclinic crystalline state $(Z=1)$ with a spacing between TTF planes of $3.601 \AA$ and the TTF groups oriented at $36^{\circ}$ to the $a$ stacking axis (Fig. 4). The shortest S...S contact between stacks is $3.707(2) \AA$. The planes formed by the so stacks interface by contacts between benzene rings where the para $\mathrm{H}$ atom of one ring is directed towards the pi system of another ring. Donor 9 which crystallizes in space group $\mathrm{P} 2{ }_{1}$ also forms similar slipped stacks, in this case along the $b$ axis, but with neighbouring stacks related by $2_{1}$ symmetry (Fig 5). The ss TTF planes lie at $35^{\circ}$ the stacking axis and are $3.620 \AA$ apart. There are close S----S contacts between the stacks of $3.417(2)$ and $3.468(2) \AA$ involving all the sulfur atoms. The planes containing these stacks interface by making $\mathrm{C}-\mathrm{H} / \mathrm{pi}$ interactions involving the unsubstituted ring of the naphthyl groups with $\mathrm{H}-$-60 pi system separations of 2.68 and $3.08 \AA$.

Cyclic voltammetry measurements at a Pt electrode in 0.1 $\mathrm{M} n-\mathrm{Bu}_{4} \mathrm{NPF}_{6}$ showed all donors to have two oxidation processes under $1 \mathrm{~V}$ (relative to $\mathrm{Ag} / \mathrm{AgCl}$ ), with the donors 7 and 9 showing slightly higher oxidation potentials than donors 8 and $\mathbf{1 0}(0.40$ $\left.{ }_{65} 0.41 \& 0.88-0.90 \mathrm{~V} c f .0 .36 \& 0.86 \mathrm{~V}\right)$. The challenge now is to incorporate the crystal packing arrangements of donors $\mathbf{8}$ and $\mathbf{1 0}$ into their electroactive radical cation salts.

\section{Notes and references}

${ }^{a}$ School of Science and Technology, Nottingham Trent University, Clifton 70 Lane, Nottingham NG11 8NS, UK

${ }^{b}$ Davy-Faraday Research Laboratory, 3rd Floor, Kathleen Lonsdale Building, University College London, Gower Street, London, WC1E 6BT ${ }^{C}$ EPSRC National Crystallography Service, School of Chemistry,

University of Southampton, Highfield, Southampton, SO17 1BJ.

$75 \uparrow$ Electronic Supplementary Information (ESI) available: Experimental details for preparations. See DOI: $10.1039 / \mathrm{b} 000000 \mathrm{x}$

1. J.D. Dunitz, A. Karrer, J.D. Wallis, Helv. Chim. Acta, 1986, 69, 69.

2. G.L.J.A. Rikken, J. Folling, P. Wyder, Phys. Rev. Lett., 2001, 87, $236602 / 1$; V. Krstic, S. Roth, M Burghard, K. Kern, G.L.J.A.

so Rikken, J. Chem. Phys, 2002, 117, 11315.

3. J.P. Griffiths, N. Hui, R.J. Brown, P. Day, J. D. Wallis, J. Org. Biomol. Chem., 2005, 3, 2155. R. J. Brown, A.C. Brooks, J.-P. Griffiths, B. Vital, P. Day, J. D. Wallis, Org. Biomolec. Chem., 2007, 3172; C. Réthoré, M. Fourmigué, N. Avarvari, Chem.

85 Commun., 2004, 1284.

4. M. Chas, M. Lemarié, M. Gulea, N. Avavari, Chem. Commun., 2008, 220 .

5. C. Réthoré, N. Avavari, E. Canadell, P. Auban-Senzier, M. Fourmigué, J. Am. Chem. Soc., 2005, 127, 5748; S. Matsumiya, A.

so Izuoka, T. Sugawara, T. Taruishi, Y. Kawada, M. Tokumoto, Bull. Chem. Sac.Japan, 1993, 66, 1949.

6. E. Coronado, J.R. Galan-Mascaros, C.J. Gomez-Garcia, A. MurciaMartinez, E. Canadell, Inorg. Chem., 2004, 43, 8072;

7. L. Martin, P. Day, H. Akutsu, J.-I. Yamada, S. Nakatsuji, W. Clegg. 95 R.W. Harrington, P.N. Horton, M.B. Hursthouse, P. McMillan, S. Firth, CrystEngComm, 2007, 9, 865.

8. L. Martin, S.S. Turner, P. Day, K.M. Abdul Malik, S.J. Coles, M.B. Hursthouse, Chem. Commun., 1999, 513.

9. L. Martin, P.Day, private communication.

100 10. D.M. Amabilino, J. Veciana in Topics in Current Chemistry, 265 : Supramolecular Chirality, Ed. M.Crego-Calama, D.N. Reinhoudt, Springer, 2006, p. 253.

11. N. Kobayashi, T. Naito, T. Inabe, Adv. Mater. 2004, 16, 1803;A. Rajca, S.Rajca, M. Pink, M. Miyasaka, Synlett, 2007, 1799.

10512 . J. O. Jeppesen, K. Takimiya, F. Jensen, T. Brimert, K. Nielsen, N. Thorup, J. Becher, J. Org. Chem., 2000, 65, 5794; J. Jeppesen, K. Takimiya, F. Jensen, J. Becher, Org. Lett., 1999, I, 1291. 
13. 7: m.p. $187-189^{\circ} \mathrm{C}(\mathrm{dec}) ; \delta_{H}\left(\mathrm{CDCl}_{3}\right): 7.26\left(8 \mathrm{H}, \mathrm{m}, 2 / \mathrm{Ar}-\mathrm{H}_{4}\right), 7.19$ $\left(2 \mathrm{H}, \mathrm{m}, 2 \backslash \mathrm{Av}-H_{l}\right), 3.64(2 \mathrm{H}, \mathrm{q}, \mathrm{J}=6.6 \mathrm{~Hz}, 2 / \mathrm{CH}), 3.53(4 \mathrm{H}, \mathrm{m}, 4-$ , $\left.4^{\prime}-, 6-, 6^{\circ}-H_{d}\right), 3.43\left(4 \mathrm{H}, \mathrm{m}, 4-, 4^{\circ}-, 6-, 6^{\prime}-H_{\beta}\right), 1.32(6 \mathrm{H}, \mathrm{d}, \mathrm{J}=6.6 \mathrm{~Hz}$. $\left.2 / \mathrm{CH}_{3}\right) ; \delta_{\mathrm{C}}\left(\mathrm{CDCl}_{3}\right): 144.4,129.6,128.6,127.1\left(2 / \mathrm{Ar}-\mathrm{C}_{6}\right), 127.3$ $\left(3 \mathrm{a}-3 \mathrm{a}^{*}-6 \mathrm{a}-, 6 \mathrm{a}^{3}-C\right), 117.4\left(2-, 2^{2}-C\right), 65.2\left(2 \backslash C \mathrm{HCH}_{3}\right), 55.9\left(4-, 4^{*}-\right.$ , $\left.6-66^{\prime}-C\right), 22.9\left(2, C^{\prime} H_{3}\right) ; v_{\text {max }}($ ATR $): 2973,2885,2789,1489,1450$. $1367,1322,1305,1278,1206,1178,1158,1135,1078,1058,1028$, $957,902,837.759,698,548 \mathrm{~cm}^{-1} ; m / z:$ ( EI ) $494[\mathrm{M}]^{+}$; HRMS ( EI ) found: 494.0970, $\mathrm{C}_{26} \mathrm{H}_{26} \mathrm{~N}_{2} \mathrm{~S}_{4}$ requires: 494.0973; found $\mathrm{C}_{4} 63.06$; $\mathrm{H}, 5.38 ; \mathrm{N}, 5.49 \%, \mathrm{C}_{26} \mathrm{H}_{26} \mathrm{~N}_{2} \mathrm{~S}_{4}$ requires $\mathrm{C}, 63.12 ; \mathrm{H}, 5.30 ; \mathrm{N}$, $5.66 \%,{ }^{299}[\mathrm{a}]_{\mathrm{D}}=-44.5^{\circ}\left(\mathrm{c}=0.2, \mathrm{CHCl}_{3}\right) .8:$ m.p. $172-174^{\circ} \mathrm{C} ; \delta_{H}$ $\left(\mathrm{CDCl}_{3}\right): 7.23\left(6 \mathrm{H}, \mathrm{m}, 2 \backslash \mathrm{Ar}-\mathrm{H}_{3}\right), 7.04\left(4 \mathrm{H}, \mathrm{m}, 2 \backslash \mathrm{Ar}-\mathrm{H}_{2}\right), 6.45(4 \mathrm{H}$, s, 4-, 4'-6-, 6- $-\mathrm{H}), 5.12\left(2 \mathrm{H}\right.$, br, $\left.2 / \mathrm{CHCH}_{3}\right), 1.71(6 \mathrm{H}, \mathrm{d}, \mathrm{J}=6.9 \mathrm{~Hz}$, $\left.2 \backslash \mathrm{CH}_{3}\right): \delta\left(\mathrm{CDCl}_{3}\right): 142.5$ (br). 128.7, 127.7, $125.8\left(2 / \mathrm{Ar}-\mathrm{C}_{6}\right)$. $119.0\left(4-, 4^{2}-6-66^{\circ}-C\right.$ ), 112.0 (br, 2-.2'-3a-.3a'-6a-,6a'-C), 58.8 (br. $\left.2, \mathrm{CHCH}_{3}\right), 22.2(\mathrm{br}, 2 \backslash \mathrm{CH} 3) ; v_{\max }$ (ATR): $2972,2926,1453,1373$, $1360,1297,1260,1139,1123,1074,1044,1008,991,915,792$. 776. $757.703,693,606,544,520,493 \mathrm{~cm}^{-1}$; $m / z$ : (EI) $490\left[\mathrm{Ml}^{+}\right.$; HRMS (EI) found: [M] ${ }^{+} 490.0659, \mathrm{C}_{26} \mathrm{H}_{22} \mathrm{~N}_{2} \mathrm{~S}_{4}$ requires: 490.0660 ; found C. $63.55: \mathrm{H}, 4.37$, N. $5.60 \%, \mathrm{C}_{26} \mathrm{H}_{22} \mathrm{~N}_{2} \mathrm{~S}_{4}$ requires C. 63.51 : H. 4.52; N, 5.71\%; ${ }^{293}[\alpha]_{\mathrm{D}}=+48.1^{\circ}\left(\mathrm{c}=0.4, \mathrm{CHCl}_{3}\right) ; 9$ : m.p. 182$184^{\circ} \mathrm{C} ; \delta_{H}\left(\mathrm{CDCl}_{3}\right): 8.38\left(2 \mathrm{H}, \mathrm{d}, \mathrm{J}=7.7 \mathrm{~Hz}, 2 / \mathrm{Ar}-H_{i}\right) .7 .79(2 \mathrm{H}, \mathrm{dd}$. $\left.\mathrm{J}=7.7,1.9 \mathrm{~Hz}, 2 / \mathrm{Ar}-H_{l}\right), 7.68\left(2 \mathrm{H}, \mathrm{d}, \mathrm{J}=8.1 \mathrm{~Hz}, 2 \backslash \mathrm{Ar}-H_{l}\right), 7.56$ $\left(2 \mathrm{H}, \mathrm{d}, \mathrm{J}=6.9 \mathrm{~Hz}, 2 \backslash \mathrm{Ar}-\mathrm{H}_{l}\right) .7 .40\left(6 \mathrm{H}, \mathrm{m}, 2 \backslash \mathrm{Ar}-\mathrm{H}_{3}\right) .4 .45(2 \mathrm{H}$. q. J $\left.=6.6 \mathrm{~Hz}, 2 / \mathrm{CHCH}_{3}\right), 3.57\left(8 \mathrm{H}, \mathrm{m}, 4-, 4^{\prime}-, 6-, 6^{\circ}-H_{2}\right), 1.46(6 \mathrm{H}, \mathrm{d}, \mathrm{J}=$ $\left.6.6 \mathrm{~Hz}, 2 / \mathrm{CH}_{3}\right) ; \delta_{C}\left(\mathrm{CDCl}_{3}\right): 139.8,134.0,130.8,128.8,127.6$, $125.8,125.5,125.4,124.9,123.5\left(2 \backslash \mathrm{Ar}-\mathrm{C}_{10}\right), 129.6\left(3 \mathrm{a}, 3 \mathrm{a}^{\circ}-6 \mathrm{a}-, 6 \mathrm{a}^{\prime}-\right.$ C), $117.0\left(2-.2^{\prime}-\mathrm{C}\right), 62.0\left(\mathrm{CHCH}_{3}\right), 56.0\left(4-4^{\prime}-, 6-, 6^{\circ}-\mathrm{C}\right), 21.9\left(\mathrm{CH}_{3}\right)$; $v_{\max }($ ATR): $2974,2929,2872,1512,1440,1414,1378,1345,1333$, $1140,1118,1076,1051,983,793,773,733,701,493 \mathrm{~cm}^{-1} ; \mathrm{m} / z:($ CI ) $591[\mathrm{M}-3 \mathrm{H}]^{+}$(2), $222(100)$ : found C, $68.69: \mathrm{H}, 4.97: \mathrm{N}, 4.61 \%$. $\mathrm{C}_{34} \mathrm{H}_{30} \mathrm{~N}_{2} \mathrm{~S}_{4}$ requires $\mathrm{C}, 68.65 ; \mathrm{H}, 5.08 ; \mathrm{N}, 4.71 \% ;{ }^{993}[\alpha]_{\mathrm{D}}=+14.0^{\circ}($ $\left.\mathrm{c}=0.6 . \mathrm{CHCl}_{3}\right) ; 10: \mathrm{m} . \mathrm{p} .250^{\circ} \mathrm{C}($ dec $): \delta_{\mathrm{H}}\left(\mathrm{CDCl}_{3}\right): 7.86(2 \mathrm{H}, \mathrm{m}$, $\left.2 / \operatorname{Ar}-H_{i}\right), 7.80\left(2 \mathrm{H}, \mathrm{m}, 2 \backslash \mathrm{Ar}-H_{t}\right), 7.74(2 \mathrm{H}, \mathrm{d}, \mathrm{J}=8.2 \mathrm{~Hz}, 2 \backslash \mathrm{Ar}-$ $\left.H_{j}\right) 7.44\left(4 \mathrm{H}, \mathrm{m} .2 / \mathrm{Ar}-\mathrm{H}_{2}\right), 7.36\left(2 \mathrm{H}, \mathrm{t}, \mathrm{J}=7.63 \mathrm{~Hz}, 2 \backslash \mathrm{Ar}-H_{i}\right)$, $7.15\left(2 \mathrm{H}, \mathrm{d}, \mathrm{J}=7.0 \mathrm{~Hz}, 2 \backslash \mathrm{Ar}-H_{I}\right), 6.48\left(4 \mathrm{H}, \mathrm{s}, 4-4^{\prime},-6-6^{\prime}-H\right) .5 .95$ $\left(2 \mathrm{H}\right.$, br. $\left.2 / \mathrm{CHCH}_{3}\right), 1.85\left(6 \mathrm{H}, \mathrm{d}, \mathrm{J}=6.9 \mathrm{~Hz}, 2 / \mathrm{CH}_{3}\right): \delta_{\mathrm{C}}\left(\mathrm{CDCl}_{3}\right)$ : $137.4,133.8,130.5,130.5,129.0,126.7,125.8,125.5,123.4,122.4$

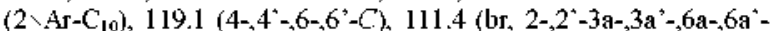
C), $55.8\left(\mathrm{CHCH}_{3}\right), 21.8\left(\mathrm{CH}_{3}\right) ; v_{\max }(\mathrm{ATR}): 3065,2980,1599,1511$. $1485,1374,1359,1294,1253,1238,1198,1170,1118,1091,1020$. $991,199,775,760,722,648,612,569,531,505,459 \mathrm{~cm}^{-1} ; m=:$ (EI) $590[\mathrm{M}]^{+}$: HRMS (EI) found: $[\mathrm{M}]^{+} 590.0977, \mathrm{C}_{34} \mathrm{H}_{26} \mathrm{~N}_{2} \mathrm{~S}_{4}$ requires: 590.0973 ; found $\mathrm{C}, 68.97 ; \mathrm{H}, 4.33 ; \mathrm{N} .4 .67 \%, \mathrm{C}_{34} \mathrm{H}_{26} \mathrm{~N}_{2} \mathrm{~S}_{4}$ requires C. 69.11: H, 4.44; N, 4.74\%; ${ }^{293}[\alpha]_{\mathrm{D}}=-239.0^{\circ}(\mathrm{c}=0.2$. THF).

14. $\operatorname{MoK}_{\alpha}(\lambda=0.71073 \AA)$ radiation, $\mathrm{T}=120 \mathrm{~K}: C_{\Gamma}$ stal data for 7 : $\mathrm{C}_{26} \mathrm{H}_{26} \mathrm{~N}_{2} \mathrm{~S}_{4}, \mathrm{M}_{\mathrm{r}}=494.73$, triclinic, $a=5.9951(12), b=6.5877(13), c$ $=15.830(3) \AA \alpha=86.69(3), \beta=83.08(3), \gamma=76.01(3)^{\circ}, V^{\prime}=$ $602.0(2) \AA^{3}, Z=1, P 1, \rho_{c}=1.36 \mathrm{~g} \mathrm{~cm}^{.3}, \mu=0.41 \mathrm{~mm}^{-1}, 5201$ unique refls, 4924 with $\mathrm{F}_{0}>4 \sigma\left(\mathrm{F}_{0}\right), R_{\text {int. }}=0.029$. Flack parameter $=$ $0.11(6), R_{i}=0.044, \mathrm{w}_{1}=0.123$; for $8: \mathrm{C}_{26} \mathrm{H}_{22} \mathrm{~N}_{2} \mathrm{~S}_{4}, \mathrm{M}_{1}=490.70$. tetragonal, $a=b=7.4847(4), c=42.565(3) \AA, V=2384.5(3) \mathrm{A}^{3} . Z$ $=4 . \mathrm{P}_{3} 2,2 . \rho_{c}=1.37 \mathrm{~g} \mathrm{~cm}^{-3}, \mu=0.42 \mathrm{~mm}^{-1}, 2670$ unique refls, 1765 with $\mathrm{F}_{0}>4 \sigma\left(\mathrm{F}_{0}\right) . R_{\text {int }}=0.097$, Flack parameter $=0.0(3) . R_{i}=$ $0.089, \mathrm{wR}_{1}=0.131$; Refinement in space group $\mathrm{P}_{1} 2_{1} 2$, using the known absolute configuration of 8 . gave a Flack parameter of $0.99(26) ;$ for 9: $\mathrm{C}_{34} \mathrm{H}_{30} \mathrm{~N}_{2} \mathrm{~S}_{4}, \mathrm{M}_{\mathrm{r}}=594.84$, monoclinic, $a=$ $12.705(3), b=6.1713(12), c=19.492(4) A, \beta=108.72(3)^{\mathrm{a}}, V=$ $1447.5(5) \mathrm{A}^{3}, Z=2, P 2_{1}, \rho_{c}=1.37 \mathrm{~g} \mathrm{~cm}^{-3}, \mu=0.36 \mathrm{~mm}^{-1}, 6504$ unique refls, 4594 with $\mathrm{F}_{0}>4 \sigma\left(\mathrm{F}_{0}\right), R_{\text {int }}=0.078$. Flack parameter $=-0.11(16), R_{t}=0.080, w R_{1}=0.134$; for $10: \mathrm{C}_{34} \mathrm{H}_{26} \mathrm{~N}_{2} \mathrm{~S}_{4}, \mathrm{M}_{1}=$ 590.81 , orthortombic. $a=10.8652(2), b=10.8969(2), c=$ $47.0032(10) A, V=5565.04(19) A^{3}, Z=8, C 222_{i}, \rho_{c}=1.41 \mathrm{~g} \mathrm{~cm}^{-3}$. $\mu=0.37 \mathrm{~mm}^{-1}, 6318$ unique refls. 5904 with $\mathrm{F}_{\alpha}>4 \sigma\left(\mathrm{F}_{0}\right), R_{\text {int. }}=$ 0.049 . Flack parameter $=0.10(11), R_{t}=0.057, w_{1}=0.154: X$-ray crystal structure were solved and refined with the SHELXS-97 and SHELYL-97 package; G.M. Sheldrick, Acta Crystallogr., 2008, A64. 112. Illustrations with computer packages ORTEP-3 for Windows. L.J. Farnugia, J. App. Cnst, 1997, 30, 565. Mercury. C. F. Macrae, P. R. Edgington, P. McCabe, E. Pidcock G. P. Shields,
R. Taylor, M. Towler and J. van de Streek, J. Appl. Cryst., 2006, 39, 453, and Diamond (Crystal Impact Gbr).

15. A.M. Kini, J.P. Parakka, U. Geiser, H.-H. Wang.F.Rivas, E. "s DiNino, S. Thonas, J.D. Dudek. J. M. Willians, J, Mater, Chem. $1999,9,883$. 